\title{
Growth and Productivity Analysis of Chemical Industry in Tamilnadu
}

\author{
Dr. P. Muthumurugan*, K. Balamurugan**, G. Elumalai*** \\ * Department of Economics, Pondicherry Central University, Puducherry-605014 \\ ** Department of Economics, Thiruvalluvar University, Vellore- 632115, Tamilnadu \\ ***Department of Economics, Madurai Kamaraj University, Madurai-625021, Tamilnadu
}

\begin{abstract}
The main purpose of this paper is to analyze the growth and productivity in Chemical industry in Tamilnadu for the period of pre and post liberalization i.e. 1980-81 to 2001-02. The labor productivity was better and the capital productivity was low during pre and post liberalization. It is necessary that both public and private investment should be enhanced in chemical research and technology for sustaining productivity growth in the long run.
\end{abstract}

Keywords: Chemical industry, Industrialization, Productivity, Research and Development, State Domestic Product (SDP)

JEL Classifications: L65, L78, O14, O25.

\section{Introduction}

Industrialization is a process of economic development where increasing proportions of home resources are mobilized to establish a technically up to date and diversified economic structure. This economy is characterized by dynamical processing industry producing means of production and consumer goods, suitable for making the fast development of the total national economic and social pressure. Industrialization is the permanent growth of the proportion of the non - agricultural sectors within the natural running with considerable growth of the total production as well as with the spread of up to date technology. A country 25 percent of whose GDP arises in the industrial sector of which atleast 60 percent is in the manufacturing sector and which has atleast one tenth of its total population employed in industry can be counted as industrialized. Thus the progress of industrialization is reflected through the following changes in the economy.

- Growth of total per capita income and SDP in the economy

- Changes in structure of industrial economy in the state

- Widespread application of scientific and technological results in practice reflected through productivity indices, capital intensity and factor substitution.

\subsection{Industrial Development in Tamilnadu}

Industrial development plays a major role in development of the state. The industrial sectors in Tamilnadu made may attempts in setting up modern industry during the period 1800-1870, however with little success from $1870^{\mathrm{s}}$ to the end of the First World War, Saw emergence of modern industry, mainly the cotton textiles. The final phase of colonial rule from 1920 to 1947 has further expansion with limited diversification.

Effective planning in Tamilnadu visually started with the techno-economic survey conducted by the National Council for Applied Economic Research (NCAER) New Delhi during 1958, although a beginning was made earlier with the commencement of national planning. The development of the industrial base of the state has been progressing along systematic lines. The pragmatic approach by the control and state governments in creating the necessarily in infrastructure and climate for an orderly growth has been greatly responsible for their development. Though, over the two decades 1950 to 1970 industrial licenses were issued to over 230 engineering industries 106 units of fertilizers and chemicals, 100 based and 226 different others industries like soap, cement, temper products, foundry etc.,

Tamilnadu state is with a solid manufacturing base. The extent of industrial development is being measured by the Index of Industrial Production (IIP). The industrial base undergoes restricting as the consumption pattern changes. Capital accumulation take place, invention and innovations are introduces in the production process.

The performance of the sector is not steady and gradual due to a multiplicity of reasons such as contagious effect of south Asian currency crisis, demand constraint in the face of tardy performance goods, credit crunch etc., in order to overcome their industrial sluggishness, the government of India and Tamilnadu state had taken proactive steps in the early nineties. In spite of despite productive measures taken in the industrial sector, this sector was in deep recession and in the doldrums. The growth of general index for Tamilnadu had increased from 1.1 percent 2001-01 to 7.9 percent in 2004-05 against 5.0 percent to 8.2 percent 
at the national level. Hence the present paper has been made an attempt to analyze the growth and productivity in chemical industry in Tamilnadu.

\section{Objectives}

The present paper attempts to describe about the growth and productivity performance of Chemical industry in Tamilnadu during 1980-81 to 2001-02. The specific objectives of the study are.

1. To confer the trend and growth of chemical industry in Tamilnadu.

2. To analyze the productivity performance of chemical industry in Tamilnadu.

\section{Literature Review}

A survey of available literature reveals the fact that studies under taken in the area of chemical industry of Tamilnadu are limited in number most of the available study in chemical industry of Tamilnadu have been under taken in recent years.

Ahluwaliah (1991) has attempted to explain the inter industry differences in Total Factor Productivity Growth (TFPG) in 62 industry groups for the period 1960 to 1986. The study analyzed TFPG on output growth along with other factors like the degree of import substitution and capital intensity growth.

Dolakia and Dholakiya (1994) examined the total factor productivity growth in Indian manufacturing. The study mainly focused on total factor productivity growth in the manufacturing industry in India. The empirical result of the study the authors considered the double deflation method is feasible with complete disaggregation available, the possibility of negative 'real' value added still remains.

Balakrishnan and Pushpangadan (1995) pointed out the total factor-productivity growth in manufacturing industry. In the study they argued that appropriate measurement of value added at constant prices is a prerequisite for the estimation of productivity. The study observed that the measurement of value added has implications for the estimated growth of TFP. Finally they concluded that there was so little reform in the $80 \mathrm{~s}$ the claim that there was improvement in productivity during this period needs to be better understood.

Sampathkumar.T (2006) has studied productivity in Indian chemical sector an intra sectoral analysis. It has divided the study period into two phases were pee reform period (1980-81 to 1990-91) and post reform period (1991-92 to 2001-2002) such as a classification of period was essential to find the impact of economic reforms on the improvements of the total productivity. The study has been estimated the trend in growth of total productivity of Indian chemical industry at the sub-sectoral level and the study sources took from ASI and RBI publications. The study also estimates TFP using Tran slog model. The result showed that TFPG of drugs and pharmaceutical paints and varnishes Basic chemical and dyes and dyestuff industries are better in the period of post reform as the change is significance and the decline in extent of negative productivity growth. It suggested that while making policy decisions based on aggregates, the consideration of intra-sectoral variation would provide more decisions that are valuable.

Ray (2012) examined the determinants of total factor productivity growth in selected manufacturing industries in India. The study period was covered a 25 years during 1979-80 to 2003-04 with seven Indian manufacturing industries namely, Cement, Aluminum, Glass, Fertilizer, Paper and pulp products, Iron \& Steel, Chemical etc. In this study divided the period in to two phases as pre-reform period (1979-80 to 1991-92) and post-reform period (1991-92 to 2003-04), sub-division of period being taken logically as such to assess conveniently the impact of liberalization. The result of the study was an individual sector reveals that export is a negative determinant of total factor productivity growth in most of the energy intensive industries in India.

\section{Methodology and Database}

This paper entirely based on secondary data obtained from Annual Survey of Industries (ASI), Ministry of Statistical Programme Implementation (MoSPI), Central Statistical Organization (CSO), Tamilnadu Statistical Hand book etc. The study has been covered 22 years from 1980-81 to 2001-02. It has witnessed the different industrial policy implementations in India and to identify the effect of liberalization policy. The total study period is divided into two sub-periods such as:

- Period-I (1980-81 to 1990-91)-----------Pre-Liberalization

- Period-II (1991-92 to 2001-02)------------Post-Liberalization

The growth performance has been discussed by taking into consideration of selected variables. All the value factors used in the study was deflated by suitable price index. For analyze the trend used by linear growth rate. To analyze the factor productivity calculated to discuss the performance of productivity in chemical industry in Tamilnadu. To standardize the data, the initial year of the study is taken as the base year. Thus all the value factors were deflated by suitable price index based on 1993-94=100.In order to construct the price indices based on 1980-81, Splicing index were used to convert the different base indices into a continuous series of a single base year. After that the base year was shifted to 1993-94 base price indexes. 


\section{Analysis of Data}

There are many contributing factors in the improvement of any industry, Structure size, composition; Labour strength and capital are the important factors mention a few, before analyzing the efficiency or relative efficiency of the inputs in the production process. It would be a worthwhile attempt to analyze the growth and structure of the chemical industry in Tamilnadu.

Table: 1

Linear growth rate of Chemical industry in Tamilnadu

\begin{tabular}{|c|l|c|c|c|}
\hline $\begin{array}{c}\text { SI. } \\
\text { No. }\end{array}$ & Variables & $\begin{array}{c}\text { Pre- } \\
\text { Liberalization } \\
\text { period }\end{array}$ & $\begin{array}{c}\text { Post- } \\
\text { Liberalization } \\
\text { period }\end{array}$ & Overall period \\
\hline 1 & No. Of Factories & 3.64 & 5.53 & 7.46 \\
\hline 2 & Total person engaged & 3.89 & 2.96 & 5.12 \\
\hline 3 & Total emoluments & 7.14 & 5.31 & 8.06 \\
\hline 4 & Gross value Added & 9.21 & 10.99 & 13.79 \\
\hline 5 & Fixed Capital & 27.67 & 29.39 & 58.00 \\
\hline
\end{tabular}

Source: Author's Calculation

The table. 1 reveals that the growth rate of chemical industry in Tamilnadu during the period 1980-81 to 2001-02. The growth rate of selected variable at constant price shows that during period except total emoluments and total person engaged all other variables shows increasing growth rate.

Figure: 1

Linear growth rate of Chemical industry in Tamilnadu

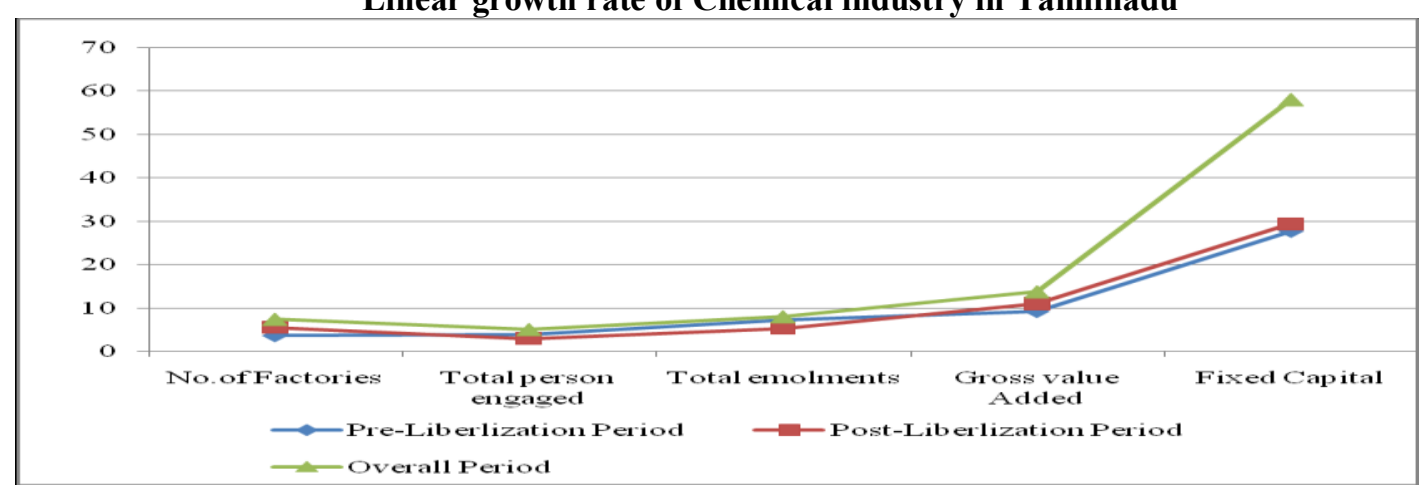

Among the increasing growth rate variables is number of factories and fixed capital have shown an impressive performance. Thus it is concluded that growth performance of chemical industries was relatively satisfactory during post liberalization period (1991-92 to 2001-02).

Moreover the Table 1 reveals that number of persons engaged in Chemical industry has delivered during post liberalization period. The improvement in the Gross value added during Post-liberalization period may be due to increase in the fixed capital in this period.

Table.2.Shows that the labour productivity of chemical industry has increased from 0.61 in 1980-81 to 1.08 in 2001-02.It reached its peals at 1.08 in 1999-2000. During pre liberalization period, labour productivity of Tamilnadu chemical industry declined from 0.61 to 0.56 from $1980-81$ to $1990-91$.

During post-liberalization the labour productivity of Tamilnadu chemical industry has increased from 0.81 to 1.08 . The labour productivity of Tamilnadu chemical industry increased from 0.61 to 1.08 in $1980-81$ to 2001-02. The labour productivity increased in after liberalization period from 0.81 to 1.0.The labour productivity of chemical industry in Tamilnadu reached its peak 1.59 in 2001-02.

Table.2

Labor and Capital productivity during 1980-81 to 2001-02

\begin{tabular}{|c|c|c|c|}
\hline \multirow{11}{*}{$\begin{array}{c}\text { Pre-Liberalization } \\
\text { period }\end{array}$} & Year & $\begin{array}{c}\text { Labour } \\
\text { Productivity }\end{array}$ & Capital Productivity \\
\hline & $1980-81$ & 0.61 & 0.85 \\
\hline & $1981-82$ & 0.66 & 1 \\
\hline & $1982-83$ & 0.78 & 1.06 \\
\hline & 1983-84 & 0.83 & 0.99 \\
\hline & $1984-85$ & 0.69 & 0.69 \\
\hline & $1985-86$ & 0.73 & 0.77 \\
\hline & $1986-87$ & 0.61 & 0.45 \\
\hline & $1987-88$ & 0.62 & 0.42 \\
\hline & $1988-89$ & 0.97 & 0.64 \\
\hline & $1989-90$ & 0.73 & 0.42 \\
\hline
\end{tabular}




\begin{tabular}{|c|c|c|c|}
\hline & 1990-91 & 1.03 & 0.56 \\
\hline \multirow{11}{*}{$\begin{array}{c}\text { Post-Liberalization } \\
\text { period }\end{array}$} & 1991-92 & 0.7 & 0.4 \\
\hline & 1992-93 & 0.84 & 0.39 \\
\hline & 1993-94 & 0.98 & 0.4 \\
\hline & 1994-95 & 0.91 & 0.35 \\
\hline & $1995-96$ & 0.9 & 0.31 \\
\hline & $1996-97$ & 0.74 & 0.2 \\
\hline & $1997-98$ & 1.12 & 0.27 \\
\hline & 1998-99 & 1.59 & 0.39 \\
\hline & 1999-2000 & 1.16 & 0.25 \\
\hline & $2000-01$ & 1.08 & 0.22 \\
\hline & $2001-02$ & 0.98 & 0.33 \\
\hline
\end{tabular}

Source: Author's Calculation

Figure: 2

Labor and Capital productivity Pre- Liberalization period

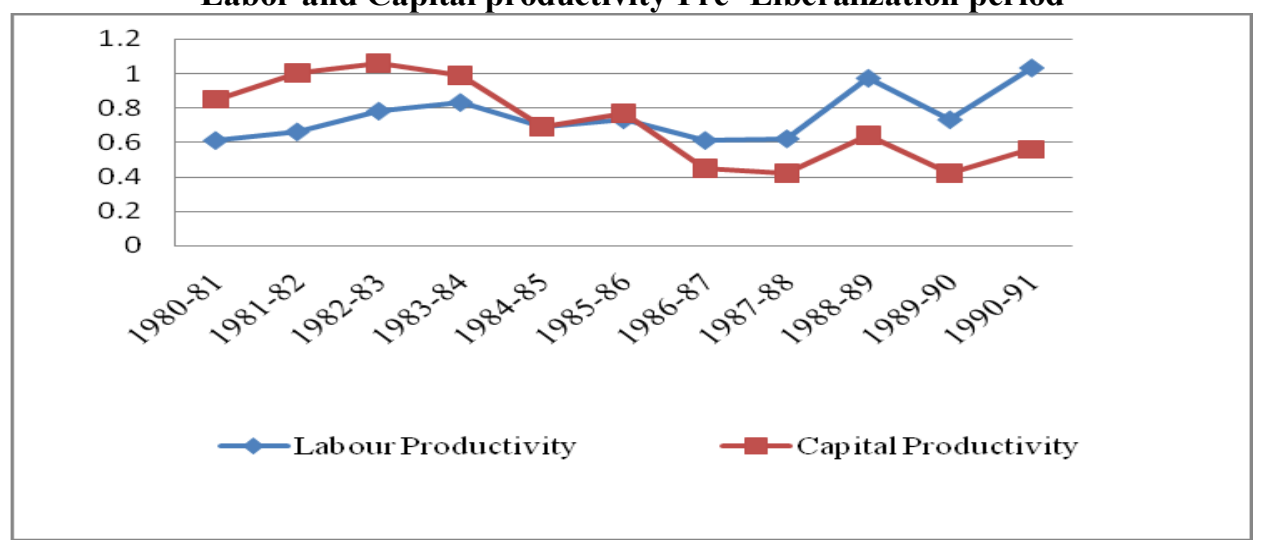

Figure: 3

Labor and Capital productivity Post- Liberalization period

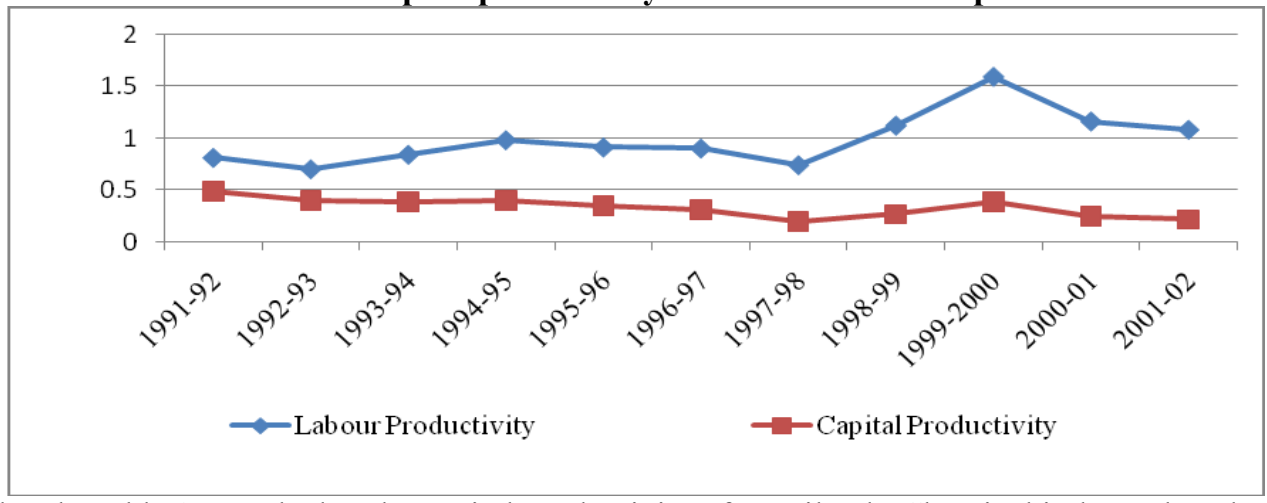

Also the table. 2 reveals that the capital productivity of Tamilnadu Chemical industry has declined from 0.85 to 0.22 during 1980-81 to 2001-02. It is very low performance for capital productivity in Tamilnadu during pre liberalization period in post liberalization period also the capital productivity has declined from 0.49 and 0.22 . The performance of capital productivity was low both during pre liberalization and post liberalization period.

\section{Findings and Conclusion}

The following major findings and conclusions are emerged from the analysis of growth and productivity in Chemical industry in Tamilnadu during 1980-81 to 2001-02:

* Tamilnadu chemical industry witnessed a growth rate of 7.46 percent in Number of factories, 5.12 percent per in Total persons engaged, 8.06 percent in Total emoluments, 13.79 percent in Gross Value Added (GVA) and Fixed capital for 58 percent during the period 1980-81 to 2001-02.

* While compared with the two sub-periods, there was higher growth rate GVA, Fixed capital growth rate, Number of factories, Total emolument and lower growth rate of Total person engaged a post liberalization period than the pre liberalization period.

* Labour productivity of Tamilnadu chemical industry rose from 0.61 to 1.03 per cent during pre liberalization period. During post liberalization period, the labour productivity increased from 0.81 to 1.08 per cent. 
The capital productivity of chemical industry is declined from 0.85 to 0.56 per cent during the pre liberalization period. The capital productivity of chemical industry is very low from 0.49 to 0.22 per cent during post liberalization period.

Finally, the paper concludes that the labour productivity was better one but capital productivity was low during pre and post liberalization period. Eventhough this paper suggests if the government allocates funds, subsidies and financial assistances for an enhance the capital and especially government has to more concentrated on Research and Development (R\&D) which will lead betterment of the growth of Chemical industry in Tamilnadu. It is necessary that both public and private investment should be enhanced in chemical research and technology for sustaining productivity growth in the long run.

\section{References}

[1] Bakul H. Dholakia and Ravindra H. Dholakia. "Total Factor Productivity Growth in Indian Manufacturing”. EPW. Vol. 29, No. 53. December 1994. Pp. 3342-3344.

[2] Balakrishnan.P and K.Pushpangadan. "Total factor productivity growth in manufacturing industry". EPW. March 1995. Pp. 462464.

[3] Muthumurugan.P and Elumalai.B "Recent trends in regional disparities in Tamilnadu". International Journal of Business Economics and Management Research. 2(7). 173-179 2012.

[4] R.B.Sutcliffe. Industry and development, Addison-Wesley Publishing Company, London, 1971, Pp.18.

[5] Sarbapriya Ray. "Determinants of total factor productivity growth in selected manufacturing industries in India", Research and Social Practices in Social Sciences, Vol. 7, No. 2, February 2012, pp. 25-43.

[6] T.Sampathkumar. "Productivity in Indian Chemical sector an inter-sectoral analysis. EPW 2006, Published by Sammekasha Trust. Mumbai.

[7] Simon Kuznets. The study of industrialization, UN. Department of Social Affairs.

[8] Ahluwaliah. "Productivity and growth in Manufacturing Industry". Oxford University Press, New Delhi, 1991. 